\title{
The Culture of Transactional Politics in Indonesia's Gubernatorial Elections Since Reformation
}

\author{
Muryanto Amin
}

Faculty of Social and Political Sciences, Universitas Sumatra Utara, JI. Dr. T. Mansyur No. 9 Medan 20155, Indonesia

\begin{abstract}
Since initiating political reform in 1998, Indonesia has sought to restructure its political institutions and processes as a means of reinforcing public autonomy. This article explores the three direct gubernatorial elections that have occurred in North Sumatra since the process was first implemented, namely in 2008, 2013, and 2018. We interviewed key actors, including gubernatorial candidates, political party leaders, and electoral agents, and analyzed the cultural practices of corruption and bribery. The first three local elections' examinations of North Sumatra reveal that transactional politics occurred through the practice of corruption and exchange of public offices, thereby having a deleterious effect on public services of the North Sumatra Provincial Government. Moreover, local culture tends to accept to provision and receipt of bribes and gratuities during local elections. This study contributes to the discourse on the beliefs and practices that go against the values of democracy and threaten established political systems.
\end{abstract}

Keywords: Indonesia, Transactional Politic, Gubernatorial Election, Money Politic, Political System.

\section{INTRODUCTION}

Several studies have shown that elections in Indonesia, including direct gubernatorial elections, involve high levels of transactionalism while ignoring legal guidelines and good governance practices (Carty, 1981; Masaaki \& Rozaki, 2006, Hadiz, 2005). Often, would-be candidates provide financial and material goods to party elites in order to be selected for electoral contestation. Such transactions have been common in the direct gubernatorial elections that have been implemented since Indonesia began its political reform, and efforts to improve local government performance have thus suffered.

Cheema and Rodinelli (2007) argue that decentralization has promoted local accountability, political equity, and local responsiveness within local communities and governments. A similar argument is put forth by Sahdan (2008), who suggests that local participation and decision-making have been promoted through direct local elections. However, other studies have found that direct local elections have failed to strengthen local communities, instead of creating further distance between citizens and local government processes (cf. Bjork, 2006).

Studies of direct elections within the context of decentralization have found that they have created and driven local power struggles (van Klinken, 2002; Antlov, 2003; Hadiz, 2005; Mietzner, 2007). Scholars have found that, although direct elections were implemented

*Address correspondence to this author at the Faculty of Social and Political Sciences, Universitas Sumatera Utara, Indonesia;

E-mail: muryantoamin@usu.ac.id with the expectation that it would promote the democratic selection of local elites, they have been hindered by the practice of paternalism and mutual symbiosis during elections (Sidel, 2004; Bamba, 2006). As a result, direct elections have been used solely to advance the interests of the ruling elite and to maintain their access to state resources. Many studies (Putra, 2017; Qadir, 2014) have limited their discussion to the specific practices during direct local elections that violate democratic principles and electoral guidelines. This study, conversely, will explore transactional practices during the candidacy process: the foundation upon which all electoral processes are established.

This article, thus, seeks to answer three important questions regarding the culture of transactional politics in Indonesia, namely (1) How has transactional politics, as a violation of electoral regulations, been practiced in the recruitment and gubernatorial election processes in North Sumatra? (2) How have transactional politics and the fulfillment of commitments affected institutional performance and public service quality? and (3) How have local and national political systems and culture legitimized the practice of transactional politics? These questions will be used to investigate the link between transactional politics and poor government performance as well as the emergence of political practices and cultures that violate democratic principles and electoral regulations.

Transactional politics occur and are practiced in every stage of the electoral process, from candidate selection through post-election governance. Understanding them, thus, is important for three reasons. First, transactional political practices tend to 
be understood by the public as the means through which local elites maintain their power and access to state resources. Second, the political conflict caused by transactional politics has a detrimental effect on the local government's ability to provide public services. Third, political elites' transactional practices can create new political cultures that violate electoral law and democratic principles. Transactional politics thus requires serious attention from various parties.

\subsection{Transactional Politics in The Literature}

Petrova and Tarow (2007) discuss transactionalism within the context of electoral corruption, including political corruption, vote-buying, and racketeering (cf. Solihah, 2016). They identify transactionalism as a form of political pragmatism, understanding this social phenomenon as resulting from practical actions (Halim, 2014). To define transactional politics, it is necessary to achieve a conceptual understanding. According to Petrova and Tarow (2007), transactional politics is inexorably linked to money politics; indeed, money is commonly used for political expression (cf. Wright, 1976). To further understand transactional politics, it is thus necessary to understand its mechanisms and practices and their effects.

\subsection{Concepts and Mechanisms of Transactional Politics}

Petrova and Tarow (2007) define transactional politics as involving organized interactions between political parties, authorities, and institutions. They argue that there is a logical link between participation and inter-actor relationships, even as these concepts are analytically distinguished and exist independently. Transactional politics is closely correlated with money politics, as both are used for political expression and participation, and both become embedded in political culture through continued practice (Bevier, 1985; Wright, 1976). As a form of transactionalism, money politics refers to the provision of financial incentives (such as campaign contributions) as a means of political communication. In such cases, money has a communicative purpose, one that can influence political behavior; it is used as a political tool, a signal of support or means of persuasion for elected officials and the electorate, and thus influences political activities. As such, the discussion of transactional politics necessitates discussion of money (Bevier, 1985).

In Indonesia, transactional politics has become a common social practice (Utari, 2016; Saidah et al., 2018; Subekhan, 2018), and local elections have thus provided fertile ground for money. Utari (2016) explains that transactional politics (including money politics) occurs in several stages. First, would-be candidates provide financial incentives to political parties in order to persuade them to provide political support. These candidates then accumulate financial resources, which they use to hire campaign teams, shape public opinion, and conduct campaign activities. Candidates also use the money to mobilize support and accumulate electoral momentum. Some candidates give bribes and gratuities to party functionaries, entrepreneurs, electoral commission members, and even members of the voting public.

Political transactions, including money politics, involve mutualistic relationships between perpetrators (parties, politicians, and brokers) and victims (voters). All of these actors reap some benefit from money politics. For politicians, it offers an instant medium for accumulating (buying) votes. For voters, meanwhile, money politics offers a semiregular source of income, one that is more "real" than the programs promised by candidates (Ratnasari, 2016). According to Ratnasari (2016), such transactional practices ultimately show that candidates lack the qualities and competencies necessary to promote good governance, and as such, they resort to illegal and immoral means of accumulating support (i.e. persuading voters through fiscal incentives). At the same time, political parties are incapable of realizing their ideal purposes (political socialization, political communication, conflict management, interest articulation, interest aggregation, and connecting constituents with the government), instead of being trapped in an ouroboros of internal conflict (Sulardi \& Sulistyaningsih, 2017).

\subsection{Types and Impact of Transactional Politics}

Within the context of transactional politics, Sirajuddin (2016) shows that the practice of money politics in local elections is an open secret. According to a survey by Transparency International Indonesia, money is involved in the electoral process from the beginning of the registration process, when candidates seek the backing of parties or coalitions (Sulardi and Sulistyaningsih, 2017). Rohmawati shows that, in such transactionalism, money (belonging to candidates or donors) is given to other actors to buy votes or otherwise reap political benefits; in other words, money politics is a conscious practice (Rohmawati, 2013).

Money politics may be practiced in Indonesia, for example, through 'dawn attacks' (serangan fajar), the 
distribution of money to one or more voters in order to ensure a candidate's electoral victory. These dawn attacks predominantly target lower- or middle-class voters, and most frequently occur in the lead-up to election day (Subekhan, 2018). Other types of transactional politics include political bartering, political puppetry, and high-cost politics. Solihah (2016) defines political bartering as a creation of political agreements between candidates and parties to manipulate candidacy processes. Political puppetry, meanwhile, is defined by Ashiddiqi as occurring when parties recognizing that a strong incumbent is running for reelection - select a candidate to run a losing campaign; this generally has pragmatic reasons (Solihah, 2016).

Transactional politics have specific and detrimental effects (Fitriyani, 2018; Wulandari \& Perludem, 2017). Several studies in Indonesia have found that transactional politics erode democratic principles, with pure and sincere aspirations being bought to advance individuals' own interests. Consequently, voters have lost their faith in the political leadership and their elected representatives. This, in turn, has had deleterious effects on national life, with social fragmentation threatening Indonesia's continued security and corruption undermining its democratic system (Fitriyani, 2018). Samuels hypothesizes that campaign funding significantly affects elections in new democracies, with donors' money being exchanged for the ability to influence public policy and political services. Demand for donor money is driven by intense electoral competition, both within and between parties, as well as a desire to establish a collective and/or individual reputation. Politicians and donors maintain regular communication, and ultimately transactional mechanisms are established between them (Samuels, 2001).

\section{METHODOLOGY}

This study seeks to discuss transactional politics within the context of the 2008, 2013, and 2018 North Sumatran gubernatorial elections. It applies a qualitative approach, verifying its data through triangulation and contextual analysis. Data were collected through in-depth interviews with informants, including all candidates who contested the elections. Interviews were also conducted with party administrators at the local and national level in order to ascertain the processes and mechanisms used by parties to select their candidates. To ensure the validity and reliability of data, the results were crosschecked through interviews with other actors involved in the electoral process, including campaign team members.
Complementing these interviews, focus group discussions were held with various stakeholders, including academics, civil society activists, members of the Local General Election Commission and the Election Monitoring Agency of North Sumatra (both responsible for the implementation of direct elections), political party representatives familiar with candidate selection procedures, and members of the public. All of these data were used to better understand the process through which gubernatorial candidates have been selected in North Sumatra. In the qualitative research, a deeper interview method can be used with several approaches, one of them is to get valid information using informants, so the secretness of their approach can be obtained.

\section{RESULTS}

This study understands transactional politics as involving the abuse of political power by distributing goods, funds, and/or services in order to achieve specific political goals and reach agreements with political parties/elites. More specifically, transactional politics refers to the strategies used by gubernatorial candidates and their allies (including the distribution of goods, funds, and/or services) to receive the political backing of parties or coalitions. The practice of transactional politics is thus evidenced by the existence of agreements to exchange goods, funds, and/or services in exchange for support. Transactional politics have a detrimental effect on the quality of public services and performance of the government, and ultimately shape political culture from the local level through the national level.

\subsection{Practices of Transactional Politics and Irregularities in Gubernatorial Recruitment Processes in North Sumatra}

North Sumatra is Indonesia's third-largest province, and its population of 14.6 million represents $18 \%$ of the national population (BPS, 2020). Demographically, it consists of eight indigenous ethnic groups and thirteen migrant groups from throughout Indonesia; the largest of these are the Javanese, who represent $43 \%$ of the province's population. North Sumatra may be divided into four regions; the East Coast and Southern Mountains are predominantly Muslim, while the West Coast and Nias Archipelago are predominantly nonMuslim (see Figure 1).

Profiles of North Sumatra's gubernatorial candidates since 2008 are presented in Figure 2 below. Information was obtained from election documents, interviews, and focus group discussions. 


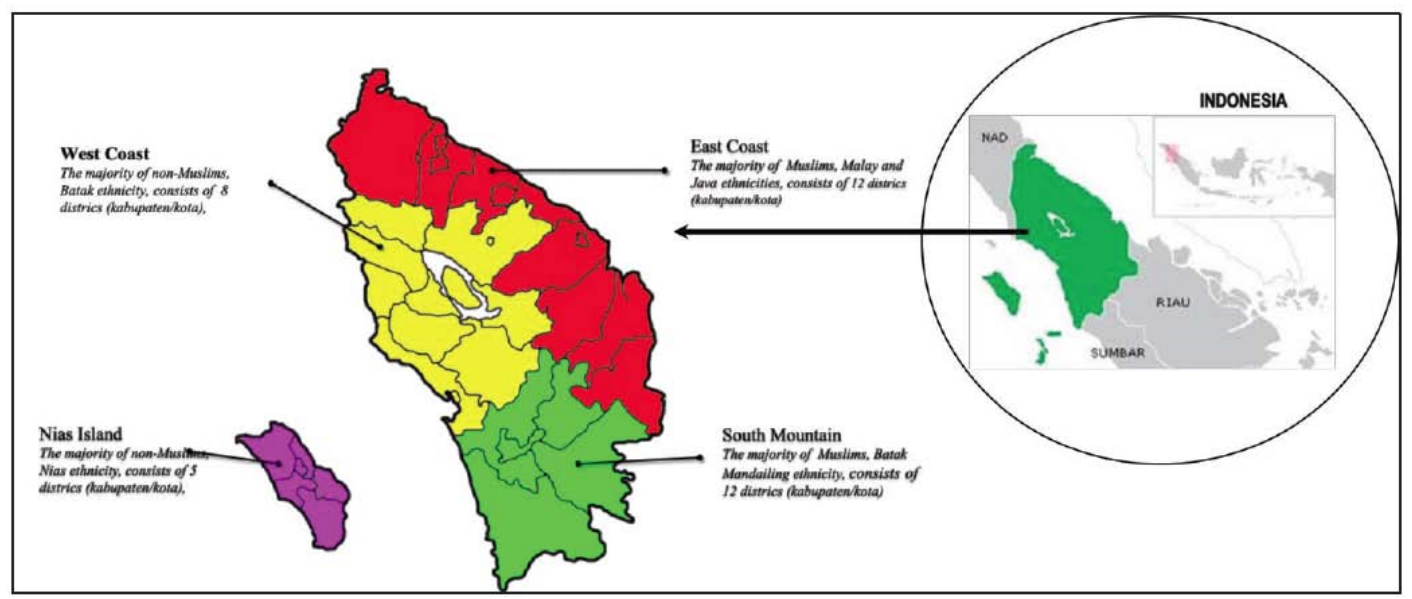

Figure 1: Demographic map of North Sumatra.

\begin{tabular}{|c|c|c|c|c|c|c|}
\hline $\begin{array}{c}\text { Candidates } \\
\end{array}$ & $\begin{array}{c}\text { Political } \\
\text { Party } \\
\text { Affiliation }\end{array}$ & Backing Party & $\begin{array}{l}\text { Ethnic Group/ } \\
\text { Territory }\end{array}$ & $\begin{array}{l}\text { Reason for } \\
\text { Candidacy }\end{array}$ & $\begin{array}{l}\text { Percentage of } \\
\text { Votes (Party) }\end{array}$ & $\begin{array}{c}\text { Number of } \\
\text { Votes } \\
(\%) \\
\end{array}$ \\
\hline \multicolumn{7}{|l|}{$\begin{array}{ll}1 . & 2008 \text { Gubernatorial Election }\end{array}$} \\
\hline $\begin{array}{l}\text { Ali Umri and Maratua } \\
\text { Simanjuntak }\end{array}$ & Golkar cadre & Golkar & $\begin{array}{l}\text { Malay, Batak } \\
\text { (East Coast, } \\
\text { West), Muslim }\end{array}$ & $\begin{array}{c}\text { Party members, } \\
\text { popular, provided } \\
\text { funding to political parties }\end{array}$ & $22,35 \%$ & $\begin{array}{c}789.793 \\
(16 \%) \\
\end{array}$ \\
\hline Tritamtomo and Benny Pasaribu & $\begin{array}{l}\text { Soldier, } \\
\text { PDIP } \\
\text { Member }\end{array}$ & PDIP, PDS & $\begin{array}{c}\text { Javanese, } \\
\text { Batak } \\
\text { (East Coast, } \\
\text { West), } \\
\text { Muslim, Non-Muslim }\end{array}$ & $\begin{array}{l}\text { Party members, } \\
\text { popular, access to campaign funds }\end{array}$ & $15,29 \%$ & $\begin{array}{l}1.070 .303 \\
(21,69 \%)\end{array}$ \\
\hline RE Siahaan and Suherdi & $\begin{array}{l}\text { Democrat, } \\
\text { Civil } \\
\text { Society } \\
\text { Organizati } \\
\text { on Activist }\end{array}$ & $\begin{array}{l}\text { PNI Marhein, PBSD, PPIB, } \\
\text { PNBK, PDS, Pelopor, PPD } \\
\text { dan PKB }\end{array}$ & $\begin{array}{c}\text { Batak, } \\
\text { Javanese } \\
\text { (West Coast, } \\
\text { East), } \\
\text { Non-Muslim, } \\
\text { Muslim }\end{array}$ & $\begin{array}{l}\text { Popular, distributed } \\
\text { funds to political } \\
\text { parties, and agreed } \\
\text { to provide access to } \\
\text { government projects and offices }\end{array}$ & $16 \%$ & $\begin{array}{l}818.171 \\
(16,58 \%)\end{array}$ \\
\hline $\begin{array}{l}\text { Abdul Wahab Dalimunthe and } \\
\text { Raden Muhammad Syafi }\end{array}$ & Golkar-PBR cadre & PBR, PAN and Demokrat & $\begin{array}{l}\text { Mandailing, } \\
\text { Javanese } \\
\text { (East Coast), Muslim }\end{array}$ & $\begin{array}{c}\text { Popular, distributed } \\
\text { funds to political } \\
\text { parties, and agreed } \\
\text { to provide access to } \\
\text { govemment projects and offices }\end{array}$ & $27,06 \%$ & $\begin{array}{l}858.528 \\
(17,40 \%)\end{array}$ \\
\hline $\begin{array}{l}\text { Syamsul Arifin and Gatot Pujo } \\
\text { Nugroho }\end{array}$ & Golkar - PKS cadre & $\begin{array}{l}\text { PPP, PKS } \\
\text { PBB and nine } \\
\text { Smaller parties }\end{array}$ & $\begin{array}{c}\text { Malay, } \\
\text { Javanese } \\
\text { (East Coast), Muslim }\end{array}$ & $\begin{array}{l}\text { Popular, distributed } \\
\text { funds to political } \\
\text { parties, and agreed } \\
\text { to provide access to } \\
\text { govermment projects and offices }\end{array}$ & $17 \%$ & $\begin{array}{l}1.396 .892 \\
(28,31 \%)\end{array}$ \\
\hline \multicolumn{7}{|l|}{ 1. 2013 Gubernatorial Election } \\
\hline $\begin{array}{l}\text { Gus Irawan and Pasaribu- } \\
\text { Soekirman }\end{array}$ & Banker -PAN cadre & $\begin{array}{l}\text { Gerindra, PIB, PBB, } \\
\text { Pelopor }\end{array}$ & $\begin{array}{l}\text { Mandailing, } \\
\text { Javanese } \\
\text { (South, East), } \\
\text { Muslim }\end{array}$ & $\begin{array}{l}\text { Popular, distributed } \\
\text { funds to political } \\
\text { partics, and agreed } \\
\text { to provide access to } \\
\text { government projects and offices }\end{array}$ & $21,3 \%$ & $1.027 .433(21,13 \%)$ \\
\hline $\begin{array}{l}\text { Effendi MS Simbolon and } \\
\text { Jumiran Abdi }\end{array}$ & PDIP cadre & PDI-P and PPRN & $\begin{array}{c}\text { Batak, } \\
\text { Javanese } \\
\text { (West Coast, } \\
\text { East), } \\
\text { Non-Muslim-Muslim } \\
\end{array}$ & $\begin{array}{c}\text { Party members, not } \\
\text { yet popular, access to campaign funds }\end{array}$ & $21 \%$ & $\begin{array}{l}1.183 .187 \\
(24,34 \%)\end{array}$ \\
\hline $\begin{array}{l}\text { Chairuman Harahap and Fadly } \\
\text { Nurzal }\end{array}$ & $\begin{array}{l}\text { Attomey } \\
\text { General- } \\
\text { PPP }\end{array}$ & $\begin{array}{c}\text { Golkar, PPP, } \\
\text { Buruh, } \\
\text { Republikan, and PPI }\end{array}$ & $\begin{array}{c}\text { Mandailing, } \\
\text { Malay } \\
\text { (East Cooast), } \\
\text { Muslim }\end{array}$ & $\begin{array}{l}\text { Popular, distributed } \\
\text { funds to political } \\
\text { parties, and agreed } \\
\text { to provide access to } \\
\text { government projects and offices }\end{array}$ & $20 \%$ & $\begin{array}{l}452.096 \\
(9,30 \%)\end{array}$ \\
\hline $\begin{array}{l}\text { Amri Tambunan and RE } \\
\text { Nainggolan }\end{array}$ & $\begin{array}{l}\text { Demokrat } \\
\text {-Traditional } \\
\text { Elder }\end{array}$ & Demokrat & $\begin{array}{c}\text { Batak, Batak } \\
\text { (West Coast), } \\
\text { Muslim, Non-Muslim }\end{array}$ & $\begin{array}{l}\text { Party members, } \\
\text { popular, access to } \\
\text { campaign funds, } \\
\text { and agreed to } \\
\text { provide access to } \\
\text { government projects and offices }\end{array}$ & $27 \%$ & $\begin{array}{l}594.414 \\
(12,23 \%)\end{array}$ \\
\hline \multicolumn{7}{|l|}{ 1. 2018 Gubernatorial Election } \\
\hline $\begin{array}{l}\text { Edi Rahmayadi and Musa } \\
\text { Rajeckshah }\end{array}$ & $\begin{array}{l}\text { Soldier - } \\
\text { Entreprene } \\
\text { ur }\end{array}$ & $\begin{array}{l}\text { Gerindra, PKS, PAN, } \\
\text { Golkar, Nasdem, Hanura, } \\
\text { Perindo, PBB, Garuda, } \\
\text { Demokrat } \\
\end{array}$ & $\begin{array}{l}\text { Malay, Arab } \\
\text { (East Coast), } \\
\text { Muslim }\end{array}$ & $\begin{array}{l}\text { Popular, had access } \\
\text { to campaign funds, } \\
\text { and agreed to } \\
\text { provide access to } \\
\text { government projects and offices }\end{array}$ & $57 \%$ & $2.986 .648(57.67 \%)$ \\
\hline $\begin{array}{l}\text { Djarot Syaiful Hidayat and Sihar } \\
\text { Sitorus }\end{array}$ & $\begin{array}{c}\text { PDIP - } \\
\text { Entrepreneur }\end{array}$ & PDIP and PPP & $\begin{array}{c}\text { Javanese, } \\
\text { Batak } \\
\text { (East Coast, } \\
\text { West) } \\
\text { Muslim, Non-Muslim } \\
\end{array}$ & $\begin{array}{l}\text { Party members, not } \\
\text { yet popular, and had access to } \\
\text { campaign funds }\end{array}$ & $23 \%$ & $\begin{array}{l}2.192 .649 \\
(42.33 \%)\end{array}$ \\
\hline JR Saragih and Ance Silian & Demokrat - PKB cadre & Demokrat and PKB & $\begin{array}{c}\text { Batak, } \\
\text { Mandailing } \\
\text { (West Coast, } \\
\text { East), } \\
\text { Non-Muslim, Muslim }\end{array}$ & $\begin{array}{l}\text { Party members, } \\
\text { popular, and had } \\
\text { access to campaign } \\
\text { funds }\end{array}$ & $20 \%$ & $\begin{array}{l}\text { Disqualified by } \\
\text { General Election } \\
\text { Commission }\end{array}$ \\
\hline
\end{tabular}

Figure 2: Profile of Gubernatorial Candidates, North Sumatra (2008-2018) (Source: field research, 2019). 
Interviews and discussions with informants identified three types of transactional politics as occurring in North Sumatra. First, candidates may distribute money to agents, administrators, and political parties. Second, candidates may offer positions in government offices and state-owned enterprises to their allies. Third, candidates may promise to provide supporters with access to government projects (interviews with informants, gubernatorial candidates, and political party leaders, 2018). There are 2 elected gubernatorial, 8 candidates, 7 party leaders at provincial level, 5 party leaders in the capital, 5 electoral agents, 5 selection committee. Thus, in total, we had interview with 32 persons.

\subsection{Distribution of Money}

Documents obtained in the field showed that political parties filter potential candidates through registration, selection, and appointment processes. Several parties have open registration systems, allowing non-members to register themselves as candidates and receive political backing.

One informant, a member of a political party's candidacy committee, stated that his party conducts internal surveys to measure the popularity and electability of its members. The results of this survey are discussed by the central party leadership in Jakarta, as are the recommendations of the local party administrators. Ultimately, the party leadership chooses candidates who are popular, electable, and have access to the necessary campaign funds. If a candidate meets all of these criteria, the party may even choose a non-member.

"The candidate we chose, [we chose him] because he had been a military officer in North Sumatra. He had the logistics necessary to accumulate campaign funds. We had to appoint a party member as his deputy to ensure that our interests could be advanced if he were elected." (interview with an informant, party administrator, September 2, 2018).

A different experience was narrated by an informant who, despite being a member of a political party, had not received their backing. As the informant stated:

"I tried talking with my political party. After I didn't receive the support of the party in which I was registered, I sought another 'boat' (party). The smaller ones gave me their backing. That wasn't pere (free). I had to pay, invite them to dinner, seek recommendations from Jakarta, give party administrators 'signing fees'. They also expected access to positions in stateowned enterprises. One party demanded the deputy gubernatorial position, threatening to leave if this did not happen. The expenditures were significant; to estimate, billions of rupiah" (interview with an informant, in Medan, December 9, 2018).

A third informant, a candidate who had served as chairman of his political party, stated:

"As party chairman, I was responsible for funding party activities. If I weren't selected for governor, where would it get the money? The party needed money to consolidate in order to receive voter support. We had difficulty finding donors, and so it was paramount that we gain control of the government. [Once we had], the party could do anything. I guaranteed that, if I were elected, the party's commitments... they'd be my commitments too. Our path was the same." (interview with an informant, in Medan, October 27, 2018).

One gubernatorial candidate stated that brokers and agents helped facilitate facilitating meetings with party officials and otherwise receive party support.

"I'm a member of the party, but when I registered as a gubernatorial candidate, they decided I wasn't allowed to run because someone else could commit to the party 'higher ups'. There were agents too, so even we party members were not entirely heeded by the central party administration" (interview with an informant, in Medan, October 10, 2018).

The above-mentioned broker explained:

"A friend from Jakarta, who was close to the 'higher-ups', asked me to work with the people in Medan. If they wanted to be governor, we could handle it. I provided one candidate to the party, and after they agreed upon an 'amount', the party made its recommendation." 
One gubernatorial candidate admitted that he had had difficulty finding a running mate because his recommendation was rejected.

"I was the governor, wanted to run again. I wanted to find a deputy who shared my vision, but it was difficult... there were so many political demands. I am a party member, but in Jakarta, it's hard to find support without making commitments. As such, I had to make commitments, and find the kind of running mate they wanted. I chose my running mate in accordance with party demands." (interview with an informant, elected governor, January 5 , 2015).

One elected deputy gubernatorial candidate stated that the party had not concerned itself much with his development proposals, simply approving his multibillion-rupiah budget.

"During the internal party selection processes, development programs were not prioritized. Rather, the candidate who could meet the party's demands was chosen. I was asked to provide some money for campaign activities. The gubernatorial candidate gave the party money to receive their support and fulfill their candidacy requirements." (interview with an informant, elected deputy gubernatorial candidate, November 13, 2018).

Political parties that did not have any seats in local parliament also had their own strategies.

"I had a political party. I approached candidates who had money. Among them was one who could fulfill our demands. $\mathrm{He}$ was the former executive of a bank in North Sumatra. I called him directly, phoned him, to talk about support. He counted on our support, and we received money for our recommendation" (interview with an informant, party chairman, Medan, September 12, 2018).

This information was confirmed by another candidate, who stated that he had spent a billion rupiah to receive the support of his political party. As the informant stated:

"I went to them, the administrators of that small party, and offered myself. After a lengthy discussion, we started talking about money. At the time, I was in search of a party. Because there weren't enough large parties, I was compelled to take that small party." (Interview with an informant, Gerindra politician, Medan, September 13, 2018).

\subsection{Distribution of Public Offices}

In some cases, transactional politics occurs when donors are promised positions within government agencies and corporations. According to one informant, who won the 2008 gubernatorial election:

"If we wanted the support of a political party, aside from money, we would also have to promise them positions in stateowned corporations. If someone asked for a spot, we'd just give it, promise it. Commissioner, chairman, whatever. It was facile, perhaps, but we could call those who recommended us, get reports." (informant, elected governor, November 13, 2018).

Another informant, who served as the director of a local state-owned enterprise in North Sumatra, explained:

"I was the first person to support the governor. I was the chairman of the party in 2008. At the time, I convinced him, "If you go for it, win it. But consider me for an office in the agriculture company, okay?" After he was inaugurated, not much later I was appointed general director" (interview with an informant, director of a local stateowned enterprise, November 5, 2018).

Data on local state-owned enterprises in North Sumatra shows that, of the fifteen positions in five state-owned enterprises, ten were occupied by gubernatorial campaign team members. One informant explained:

"Positions in state-owned enterprises are offered to political parties. There is a water company, agriculture company, bank, etc. Commissioner, director. These positions are always sought by parties during gubernatorial elections."

This was confirmed by a retired bureaucrat, who also stated: 
"Yes... we have seven local state-owned enterprises (Bank of North Sumatra, North Sumatra Agriculture Company, Tirtanadi Water Company, Dhirga Surya of North Sumatra, Industry and Service Company, and Infrastructure and Structure Development Company of North Sumatra). Their directors and the members of their supervisory boards are normally appointed by the governor, sometimes upon the recommendation of the political party or local parliament." (interview with an informant, retired bureaucrat, Medan, November 19, 2018).

According to media reports, in late 2018 the government conducted open recruitment for the positions of the commissioner, supervisor, and director. However, the process ultimately did not follow applicable guidelines (Tribun Medan, December 17, 2018). One informant, discussing the offices in local state-owned enterprises, emphasized:

"Since direct gubernatorial elections were implemented, the offices of director and supervisor have become important and contested by political parties, campaign teams, and the 'allies' of the governor and deputy governor. This happened in 2008, 2013 , and in 2018 , just recently. So, to access these positions, one must approach a political party first." (interview with an informant, retired bureaucrat, Medan, November 19, 2018).

\subsection{Distribution of Government Projects}

In 2018, the Corruption Eradication Commission of Indonesia (KPK) charged 38 members of the North Sumatra Parliament with graft. The previous year, the commission had found the Speaker of Parliament guilty of corruption (Detik.com). Raharjo, the KPK commissioner, stated:

"Members of Provincial Parliament in North Sumatra have used their authority to facilitate kong kalikong (corrupt relationships) with executives. Corruption has occurred at a massive scale, including in functional and legislative authority, and facilitated further agreements between executive and legislative actors" (Kompas, 2018).
One party chairman, who also sat on the party's candidate selection committee, stated.

"The candidates supported, usually they're the ones who promise to provide access to government projects. Informally... it's not written. After being elected, candidates usually decide what projects will be entrusted to party administrators. They use all kinds of approaches. Any money from these projects... well, some of it is used for personal purposes, and part of it is given to the party to fund its activities." (interview with an informant, August 27, 2018).

Media reports have shown that these government projects are provided to political. parties in return for their support. Reinforcing this argument, an investigation by Tempo magazine (2015) showed that budget assistance peaked in North Sumatra in 2013, shortly before the gubernatorial election. One informant stated:

"I had to find a way to ensure the regents/mayors supported us. The party recommended that I provide funds to them to get their backing. That money came from the local budget. I decided to follow this recommendation, and the technical matters were handled by the chairman of the board" (interview with an informant, November 25, 2018).

A former bureaucrat provided additional information regarding the distribution of government projects following gubernatorial elections.

"I used to work for a government financial office. Party people would often come to me, ask for a 'package' (government work/project). That's not permitted, but the leader (governor) told me to acquiesce to their demands. Those party people were the ones who had supported the governor during the election, and so he gave them local government projects." (interview with an informant, November 28, 2018).

This informant testified before KPK regarding the practice of corruption in North Sumatra. As he explained:

"I had to testify to KPK numerous times. They asked me how much money was 
given to politicians, and why. That happened during the gubernatorial elections... we had to give money or jobs to party administrators, as we promised when we were seeking the support of political parties." (interview with an informant, November 28, 2018).

The above-mentioned corruption case became a national issue, and 86 members of the North Sumatra Parliament were found guilty (KPK, 2018). The use of government projects to obtain political support during gubernatorial elections was mentioned by one informant, who works in law enforcement.

"According to our records, several local government projects were entrusted to Members of Provincial Parliament because they had supported the governor during the gubernatorial election. These projects also involved 'fees', remuneration; they had to pay before starting the project."

\subsection{Local and National Political Systems and Cultures}

Transactional politics is strictly prohibited by Article 47 of Law No. 10 of 2016 regarding Gubernatorial, Regent, and Mayoral Elections. According to Paragraph 5 of this article, candidates proven to have illegally given or accepted money will automatically have their candidacies revoked. Meanwhile, according to Paragraph 2, any political parties proven to have accepted money in exchange for political support will be prohibited from fielding a candidate in the next election at the same level.

During a focus group discussion (2018) regarding the political system, political culture, and gubernatorial elections, a local political scientist stated:

"Most of the people of North Sumatra accept transactional politics as part of the candidacy process, though some are opposed, seeing it as violating the democratic principle of justice." (FGD, 2019).

Another participant added:

"We have yet to find a case where law enforcement has subjected a gubernatorial candidate to legal sanctions, even though reports are widespread" (FGD, 2019).

According to one party administrator who participated in this discussion:

"Political parties still use their internal selection processes when choosing their gubernatorial candidate, but these processes are not transparent. The interests of the political elites at the national and local level accommodate transactionalism in candidate selection in North Sumatra-though, for me, these transactions don't necessarily have to involve money." (FGD, 2019).

According to another informant, a civil society activist:

"Transactionalism in the candidacy process has been accepted as a common practice, or even habit, by the political elite. Political parties don't teach constituents about how leaders derive their power from the people or work for the collective interest. As such, they don't often protest the violations of election law in North Sumatra. Giving and receiving gratuities has become part of the tradition and culture of North Sumatra." (FGD, 2019)

A cultural leader stated that:

"The tradition of giving and accepting gratuities remains common in Malay and Batak culture. Malays still consider give and accept gratuities during rituals such as nujuh bulan (celebrating the seventh month of pregnancy) and weddings, as well as during Islamic holidays and thanksgiving ceremonies. Batak's do this too, as seen in such traditions as boras mi tondi (giving rice) and upa-upa, giving prayers and gifts to people who are recovering from disaster or who are celebrating something (interview with an informant, December 23, 2019).

"Gratuity-giving has been practiced for generations by the people of North Sumatra. It is seen as a means of maintaining relationships with other 
people. This deeply rooted culture is a major reason that giving and accepting gratuities is seen as natural and as means of showing thanks." (interview with an informant, December 22, 2018).

Another informant, a civil society activist, elucidated:

"Although most people in North Sumatra know about government corruption, if we were to ask them to demonstrate or protest, most wouldn't. It's like they understand the practice, because a lot of them go to the governor for help if they are planning an activity. Religious and professional organizations always seek the assistance of the governor. Where would he get the funds, if not from the provincial budget?" (interview with an informant, civil society activist, Medan, December 17, 2018).

\section{DISCUSSION}

As mentioned above, North Sumatra is an ethnically and religiously diverse Indonesian province. As such, ethnic and religious representation are important considerations in candidate selection processes (Figure 1). However, according to one informant, representation is far from the only factor considered by political parties when choosing and backing candidates.

Transactional politics that happen in gubernatorial elections will and obviously generate an extremely high cost to the candidates, thus when a candidate is elected, they will have a lot of loan to be paid. The money they used in the election usually the money of another person (could be businessman or company). So, when they elected, they will pay the loan by giving their partner with the projects from government. The concept of bribery and gratification is occurring when a public officer accepting bribery and gratification from the businessman who wins project from local government. The concept of of abuse of public office is when public officer is giving advantages to the businessman who has highest priority to get the project, they get highest priority because they spent money for their elected candidate. The concept of corruption is happened when specific businessman has been chosen to win a project in government.
As summarized in Figure 2 above, interviews found an interplay of several factors. First, political parties did not necessarily back their own members, but sometimes selected other candidates. Second, the results of the gubernatorial election did not always correlate linearly with parties' previous electoral performance. Third, candidates' willingness to distribute money and positions was considered as part of the selection process. Fourth, successful gubernatorial candidates ultimately entrusted government projects to their allies and supporters, thereby deleteriously affecting government performance and service quality.

\subsection{Transactional Politics and Electoral Violation in Gubernatorial Candidacies}

This study shows that transactional politics between gubernatorial candidates and political parties occurs during the candidacy process through the distribution of money, positions, and government projects. Such transactionalism violates Law No. 10 of 2006, which regulates local election, but cannot easily be proven as it involves informal discussions and occurs behind closed doors. Local elites rely on these political transactions to maintain their control over and access to state resources.

Money is frequently used in North Sumatra to facilitate the gubernatorial candidacy process. The former candidates interviewed all stated that money was crucial, a potent tool for initiating discussions and ultimately receiving parties' political support. Such transactionalism also created opportunities for political brokers to become involved in the process and help candidates meet and negotiate with party elites. Without money, communication would not occur. This reinforces previous findings about the widespread use of money politics as a form of transactional politics (Wright, 1976; Bevier, 1985). Despite legal prohibitions, candidates and party elites consciously and deliberately use money in their political transactions (Rohmawati, 2013). Money politics, thus, is a type and impact of transactional politics in Indonesia.

During the candidacy process, candidates also commit to distributing political offices to their supporters. Interviews with gubernatorial candidates and party elites found that these decisions are made jointly, with candidates making commitments before election and fulfilling them afterwards. Such commitments, which have also been identified in 
previous studies (Getz, 2008; Rahmadan, 2010; Amin, 2017), are based in mutual symbiosis between parties, politicians, and brokers. Such distribution of political offices can negatively affect the quality of local governance and promote corruption. The commitment to distribute political offices to supporters may thus be considered a mechanism of transactional politics.

Candidates and parties may also commit to distributing government projects to advance their interests and increase their income through project fees. As shown by Tempo magazine, it has been common for the North Sumatran government to distribute money to municipal governments through a bantuan daerah bawahan (subordinate area assistance) scheme. Although ostensibly meant to fund physical development, this scheme also serves to guarantee the political support of municipal officials. This scheme offers fertile ground for corruption and embezzlement, as there are no specific project criteria and accountability mechanisms are poorly defined. One informant confirmed that the distribution of money through this scheme occurs rapidly, even if this violates applicable law, as it ensures that regents and mayors have sufficient funds to campaign for the incumbent governor. Such transactionalism has offered local elites a means of accessing and controlling state resources, thereby enabling them to profit from government activities. The commitment to distribute government projects may thus be understood as a mechanism of transactional politics.

\subsection{The Effects of Transactional Commitments on Institutional Performance}

When the above-mentioned commitments are fulfilled, government performance suffers. In North Sumatra, this can be seen through three indicators. First, in reports on the accountability of government institutions issued by the Ministry of Administrative and Political Reform, the North Sumatran government has yet to score higher than 60 ('good') since direct elections were implemented. As such, it may be concluded that budget implementation remains ineffective and inefficient, which necessarily affects government performance and service quality. The North Sumatran government lacks a culture of goaloriented good governance, and as such it has been unable to realize its stated vision and mission.

Second, the North Sumatran government has failed to adequately provide the basic services of education and healthcare, both of which are necessary to shape Indonesia's future generations. Statistics Indonesia (2017), applying national standards and indicators, found that almost half of North Sumatra's classrooms are not suitable learning environments (see Table 1). Dropout rates are among the highest in the country, more than half of students are delayed in beginning their educations, and teacher competency levels are dismal (BPS, 2017). Health infrastructure is similarly lacking. More than half of government clinics are dilapidated, and medical staff are overburdened, being expected to cover the medical needs of three or four

Table 1: North Sumatra Education and Health Services 2017

\begin{tabular}{|c|c|c|c|c|}
\hline No. & Services & Amount & Good Condition & Information \\
\hline \multirow[t]{8}{*}{1.} & \multicolumn{3}{|l|}{ Education } & \multirow{7}{*}{$\begin{array}{c}\text { Only } 34.5 \% \text { of class room } \\
\text { facilities were in good } \\
\text { condition }\end{array}$} \\
\hline & Elementary School Classroom's Facility & 105,655 & 36,451 & \\
\hline & Junior High School Classroom's Facility & 39,910 & 13,769 & \\
\hline & Senior High School Classroom's Facility & 20,437 & 7,051 & \\
\hline & Vocational High School Classroom's Facility & 17,159 & 5,920 & \\
\hline & Kindergarten School Classroom's Facility & 8,869 & 3,060 & \\
\hline & Extraordinary School Classroom's Facility & 771 & 266 & \\
\hline & Sub Total & 192,802 & 66,517 & \\
\hline \multirow[t]{5}{*}{2.} & \multicolumn{4}{|l|}{ Health } \\
\hline & Public Health Center & 571 & 199 & \multirow{4}{*}{$\begin{array}{l}\text { As many as } 35 \% \text { of the } \\
\text { physical condition of the } \\
\text { puskesmas buildings is not } \\
\text { good }\end{array}$} \\
\hline & Hospital Type A & 1 & 1 & \\
\hline & Hospital Type B & 28 & 25 & \\
\hline & Doctor & 2.871 & 2.871 & \\
\hline
\end{tabular}

Source: Processed from Data Center of Ministry of Education and Ministry of Health, 2018. 
villages simultaneously. There is only one clinic for every 23,266 people, and one doctor for every 4,528 people. These conditions indicate that North Sumatra's directly elected governors have yet to prioritize education and healthcare.

Third, data from the Audit Board of Indonesia (2013) shows that the North Sumatran government has violated applicable laws in its distribution of provincial funds; this can be seen, for example, in the government giving Rp 380.4 billion worth of goods to residents as grants (BPK, 2013). An investigation by Tempo magazine similarly found that state resources were exchanged between the incumbent governor and local members of parliament as part of the gubernatorial candidacy process (Tempo, 2015). Ultimately, an Indonesian court found this governor guilty of misusing government funds to provide bribes to legislators.

Meanwhile, the governor elected in 2018 has yet to make concrete steps towards improving the performance of the North Sumatran government. Available digital media do not provide any information on program improvements, but rather deal with controversial statements and other missteps (see, for example, detik.com, December 31, 2019). This governor has also been accused of acting inappropriately when filling government positions (Medan Bisnis, February 4, 2019), reinforcing the argument that officials are appointed not because of their skill but in exchange for their political support.

These three indicators suggest that three direct gubernatorial elections have failed to improve the performance of the North Sumatran government. Available data also indicates that local government officials have been unable to prepare clear guidelines and realistic goals for their programs. Reinforcing previous findings, this study has found that elected and appointed government officials lack the qualities and competencies necessary to implement good governance (Ratnasari, 2016).

It has often been argued that decentralization and direct elections can improve local government performance. However, Crook and Manor (1998) found that, in South Asia and West Africa, these processes resulted in local political practices that violated the principles of democracy and good governance. Similarly, this study has suggested that decentralization and direct local elections has failed to improve governance in North Sumatra. Transactionalism has continued to limit the provincial government's ability to provide public services.

\subsection{Legitimization through Local and National Political Systems and Culture}

Studies of the political systems and cultures of democratic countries have found that their evolution is informed by local contexts (Verba \& Almond, 1963; Putnam, 1994; Norris, 2002). Ingelhart (1998) argues that political culture significantly affects the stability and continued practice of democracy. In this discussion, political culture refers to the shared political practices and values of a community. This may be realized, for example, through the giving and receiving of gratuities, a part of the traditional teachings of North Sumatra's major ethnic groups (Utari, 2016; Yulia \& Sari, 2018; Saidah et al., 2018; Subekhan, 2018) that continue to be practiced and embraced today.

Indonesia's national political system has formally recognized the need for a just democracy, and thus prohibited and provided legal sanctions for the giving and receiving of gratuities during political processes. Nonetheless, this study finds that North Sumatrans perceive transactionalism as occurring during the gubernatorial candidacy process, being practiced by candidates, brokers, and party leaders as a means of expressing gratitude and advancing particular interests. Gubernatorial candidates must be backed by at least one political party to contest elections; political parties need money to fund their programs; and brokers serve to link actors who share interests despite their distinct needs. These actors jointly commit themselves to the principle of 'give and take', which they perceive as an Eastern (read: Indonesian) tradition.

Indonesians tend to mimic the behaviors and attitudes of the political elite, and as such many implicitly accept the practice of transactional politics. As such, even when they recognize and understand the transactionalism that occurs during the gubernatorial candidacy process, and even with laws that strictly prohibit such practices, protests are minimal. Most Indonesians look the other way, being conditions by their political culture as well as the traditions that have developed in their community, even as it stymies the development of a democratic political system. This holds true for the people of North Sumatra, who generally perceive transactional politics as an acceptable part of local culture and accept it both at the local and national level. 


\section{CONCLUSION}

This article has explored the culture of transactional politics within North Sumatra's gubernatorial elections. Since reform began in 1998, Indonesia's political system has transformed fundamentally through decentralization and the implementation of direct local elections, both of which were intended to improve autonomy and protect Indonesians' political rights. However, in North Sumatra, transactionalism has remained common. Money politics has become an integral in candidacy processes, and candidates and political parties have established symbiotic relationships wherein they distribute government offices and projects for their mutual benefit. Consequently, even as transactional politics has deleteriously affected government performance and public services, it has become legitimized as part of the political system and culture.

Transactional politics has remained prominent in Indonesia's democratic system. Policies to mitigate its effects, or even eradicate it completely, must consider three important points. First, constituents generally accept transactional politics as a means through which political elites maintain their access to state resources. Second, transactionalism has the potential to cause political conflict, which will disturb the local government's quality and ability to provide basic services. Third, the continued practice of transactional politics is legitimized through local political culture, even as it contradicts democratic principles and endangers the national political system. In new democracies such as Indonesia, transactional politics can occur in elections at all levels. This study not only deepens knowledge of transactionalism and maps its practices at the local level, but provides a new perspective for understanding its effects.

\section{REFERENCES}

Almond, Gabriel A., Sideny Verba. 1963. The Civic Culture: Political Attitudes and Democracy in Five Nations. Princeton: Princeton University Press. 1963. https://doi.org/10.1515/9781400874569

Amin, Muryanto. 2017a. "New Patronage Networks of Pemuda Pancasila in Governor Elections of North Sumatra." The Social Sciences Journal 12(8): 1456-10.

Amin, Muryanto. 2017b. "Recruitment, Certification and Financial Management of Political Parties in the Province of North Sumatera, Indonesia." Proceedings of the 2nd International Conference on Social and Political Development. Atlantis Press. ASSEHR; 136.

Antlöv, H. 2003. "Village Government and Rural Development in Indonesia: The New Democratic Framework." Bulletin of Indonesian Economic Studies 39(2): 193-21. https://doi.org/10.1080/00074910302013
Bamba, John. 2006. "Borneo Headhunter: Imej dan Manipulasi in Okamoto Masaaki \& Abdur Rozaki. Kelompok Kekerasan dan Bos Lokal di Era Reformasi." Yogyakarta: IRE Press.

Buhori Buhori, Hanna Yulia, Velly Pranika Sari. Tradisi Nujuh Bulan Pada Masyarakat Muslim Melayu Kabupaten Melawi. West Kalimantan: Al-Hikmah 2018; p. 23-22. https://doi.org/10.24260/al-hikmah.v12i1.990

Carty, R. K. 2018. "Brokerage and Partisanship: Politicians, Parties and Elections in Ireland." Canadian Journal of Political Science (14): 53-29. https://doi.org/10.1017/S0008423900035356

Cheema, G. Shabbir, Dennis A. Rondinelli. 2017. "Decentralizing Governance: Emerging Concepts and Practices." Washington: Brookings Institution Press.

Crook, C. Richard, Manor James. 1998. "Democracy and Decentralisation in South Asia and West Africa: Participation, Accountability and Performance." Cambridge: Cambridge University Press. https://doi.org/10.1017/9780511607899

Detik.com. 2018. Nasdem Resmi Dukung Edy Rahmayadi dan ljeck di Pilkada Sumut. Election Monitoring Agency (Bawaslu). Retrieved May 12, 2019 (https://bawaslu.go.id/sites/default/ files/publikasi/6.\%20Bawaslu\%20Dalam\%20 Angka.pdf).

Dewi, S. Salamiah. 2018. "Kecerdasan Emosional dalam Tradisi Upa-Upa Tondi Etnis Mandailing." Journal of Social Cultural Anthropology 4(1): 79-6. https://doi.org/10.24114/antro.v4i1.10039

Election Monitoring Agency (Bawaslu). Data Pelanggaran Pilkada 2017 dan 2018. 2018. Retrieved May 26, 2019 (https://bawaslu.go.id/id/pengawasan?page=1).

Fitriyani, F. 2018. "Peran Santri dalam Penegakan Hukum Pemilu (Studi Kasus Praktik Politik Uang dalam Pilkades Kabupaten Demak)." National Proceedings of Law Universitas Negeri Semarang 4(3): 1009-23.

Garrick, D., McCann, L., Pannell, J. 2013. "Transaction Costs and Environmental Policy: Taking Stock, Looking Forward." Journal of Ecological Economy 88: 182-184. https://doi.org/10.1016/j.ecolecon.2012.12.022

Getz, Christy. 2008. "Social Capital, Organic Agriculture, and Sustainable Livelihood Security: Rethinking Agrarian Change in Mexico." Rural Sociology 73(4): 555-24. https://doi.org/10.1526/003601108786471521

Hadiz, R. Vedi. 2005. "Dinamika Kekuasaan, Ekonomi Politik Indonesia Pasca-Soeharto." Jakarta: LP3ES.

Hadiz, R. Vedi. 2010. "Localising Power in Post-authoritarian Indonesia: A Southeast Asian Perspective." California: Stanford University Press.

Halim, Abdul. 2014. "Dampak Sistem Proporsional Terbuka terhadap Perilaku Politik (Studi Kasus Masyarakat Sumenep Madura dalam Pemilihan Legislatif." Journal of Humanity 9(2): 122 14.

Hariyani, Hariyani. 2018. "Model Kampanye Pilkada Atasi Politik Uang dan Sikap Pesimis Pemilih: Telaah Teoritis dan Konsep Implementasinya." Journal of Communication Science 6(2): 178-14. https://doi.org/10.30659/jikm.6.2.178-193

Hidayat, Endik. 2017. "Praktik Politik Oligarki dan Mobilisasi Sumber Daya Kekuasaan di Pilkades Desa Sitimerto Pada Tahun 2016." Journal of Social Politics 14(2): 124-27. https://doi.org/10.22219/sospol.v4i2.6795

Inglehart, Ronald. 1998. "The Renaissance of Political Culture." American Political Science Review 82(4): 1203-27. https://doi.org/10.2307/1961756

Interview with informant, candidate involved in party selection processes, Medan, September 3, 2018.

Interview with informant, contestant, September 27, 2018. 
Interview with informant, Gerindra politician and Member of Parliament (2014-2019), Medan, September 13, 2018.

Interview with informant, Gerindra politician, Medan, September 13, 2018.

Interview with informant, governor elect, January 5, 2015.

Interview with informant, governor elect, Medan, December 9, 2018.

Interview with informant, governor elect, November 13, 2018.

Interview with informant, gubernatorial candidate (North Sumatra, 2008), Medan, October 27, 2018.

Interview with informant, gubernatorial candidate (North Sumatra, 2018), Medan, October 10, 2018.

Interview with informant, Member of the General Elections Commission of Indonesia, Jakarta, November 28, 2018.

Interview with informant, Member of the General Elections Commission of North Sumatra, September 20, 2018.

Interview with informant, party administrator, Medan, September 12, 2018.

Interview with informant, party administrator, November 18, 2018.

Interview with informant, party chairman, Medan, September 12, 2018.

Interview with informants, gubernatorial and deputy gubernatorial candidates, Medan, September 15, 2018.

Kholiq, Abdul. 2017. "Perilaku Politik Transaksional Menggagas Fenomena Praktik Politik Uang dalam Pemilu." Manarul Qur'an 13(2): 94-11.

Kompas. 2015. KPK: 36 Kepala Daerah dan 86 Anggota DPRD di Sumatera Tersangkut Kasus Korupsi. Retrieved April 2019 (https://nasional.kompas.com/read/2018/

11/18/13412061/kpk-36-kepala-daerahdan-86-anggota-dprddi-sumatera-tersangkut-kasus).

Kompas. 2015. Mendagri: 343 Kepala Daerah Tersangkut Kasus Hukum. Retrieved May 10, 2019 (http://nasional.kompas. com/read/2015/02/04/ 21114211/Mendagri.343.Kepala.D aerah.Tersangkut.Kasus.Hukum).

Kompas.com. 2018. KPK: Kasus 38 Anggota DPRD Sumut Tunjukkan Korupsi Dilakukan Massal. Retrieved June 19, 2019 (https://nasional.kompas.com/read/2018/ 04/03/ 19001221/kpkkasus-38-anggota-dprd-sumut-tunjukkankorupsi-dilakukan-massal).

Law No. 10 of 2016 regarding Gubernatorial, Regent, and Mayoral Elections

Masaaki, Okamoto, Abdur Rozaki. 2006. "Kelompok Kekerasan dan Bos Lokal di Era Reformasi." Yogyakarta: IRE Press.

Medan Bisnis. 2019. Rekrutmen Dewas dan Dekom BUMD, Pemprovsu Dinilai Tak Paham Aturan. Retrieved July 20, 2019 (http://www.medanbisnisdaily.com/news/online/read /2019/02/04/65409/rekrutmen_dewas_dan_dekom_bumd_pe mprovsu_dinilai_tak_paham_aturan/).

Mietzner, Marcus. 2006. "Party Financing in Post-Soeharto Indonesia: Between State Subsidies and Political Corruption." Contemporary Southeast Asia 29(2): 238-25. https://doi.org/10.1355/CS29-2B

Ministry of Administrative and Bureaucratic Reform (Kemenpan RB). 2018. Hasil Evaluasi atas Kinerja Pemerintah Pemerintah Tahun 2018; Document.

Norris, Pippa. 2012. "Democratic Phoenix: Reinventing Political Activism." Cambridge: Cambridge University Press.

Putnam, D. Robert, Leonardi Robert., Nanetti Y. Raffaella. 1994. "Making Democracy Work: Civic Traditions in Modern Italy." Princeton: Princeton University Press. https://doi.org/10.1515/9781400820740

Putra, S. Heru. 2017. "Determinants of Vote Buying in Local Head Election in Indonesia." J of Home Affairs Governance 9(2): 205-13.

https://doi.org/10.21787/jbp.09.2017.205-218
Qodir, Zuly. 2014. "Politik Uang dalam Pemilu-Pemilukada 2014: Modus dan Resolusinya." Journal of Administration and Local Government 8(2): 39-15.

Rahmadan, D. 2010. "Tinjauan Yuridis Sosiologis Partisipasi Politik dalam Pemilihan Umum Kepala Daerah dan Wakil Kepala Daerah." Journal of Constitution 3(1): 1-29.

Ratnasari, D. 2016. "Hubungan Penerimaan Money Politic dengan Tingkat Partisipasi Politik dalam Pemilihan Kepala Desa di Desa Munung Kecamatan Jatikalen Kabupaten Nganjuk." Kajian Moral dan Kewarganegaraan 4(3): 99-20.

Regulation of the General Election Committee No. 15 of 2008 regarding the Technical Guidelines for Local Executive and Deputy Executive Candidacies

Rohmawati, Tatik. 2013. "Dinamika Politik Pedesaan Dalam Pemilihan Kepala Desa Masin Kabupaten Batang Provinsi Jawa Tengah." Journal of Communication Political Science UNIKOM 3: 23-16.

Sahdan, Gregorius. 2018. "Pilkada dan Problem Demokrasi Lokal Politik Pilkada: Tantangan Merawat Demokrasi" Yogyakarta: Indonesian Power for Democracy, pp. 155-2.

Saidah, S. E., Cahya, F.N., and Wijayanti, S.E. 2018. "Analisis Yuridis Terhadap Sistem Pemilihan Kepala Desa Terkait Money Politic (Studi Kasus di Desa Pucung, Kecamatan Kismantoro, Kabupaten Wonogiri)." Legal Standing: Journal of Law Science 2(1): 55-17. https://doi.org/10.24269/ls.v2i1.1011

Samuels, David. 2001. "Money, Elections, and Democracy in Brazil." Latin American Politics and Society 43(2): 27-21. https://doi.org/10.1111/j.1548-2456.2001.tb00398.x

Saputra, S. Ananda. 2015. "Politik Uang dalam Pemilihan Legislatif di Kota Pekanbaru Tahun 2014." Online Student Journal of Social Politics Science 3(1): 1-10.

Sidel, T. John. 1997. "Philippine Politics in Town, District, and Province: Bossism in Cavite and Cebu." Journal of Asian Studies 56(4): 947-19. https://doi.org/10.2307/2658295

Simatupang, Jonasmer, Muhammad Subekhan. 2018. "Pengaruh Budaya Politik Uang dalam Pemilu Terhadap Keberlanjutan Demokrasi Indonesia." National Seminar of Law Universitas Negeri Semarang 4(3): 1297-15

Sirajuddin. Format Kekuasaan Kehakiman dalam Perubahan Lanjutan Konstitusi; 2016 [cited 2019 May 12]: Retrieved from: http://ejournal.umm.ac.id/

Smith TM. Corruption, Tradition and Change. Indonesia; 1970 [cited 2019 May 11]: https://doi.org/10.2307/3350742

Solihah, R. 2017. "Politik Transaksional dalam Pilkada Serentak dan Implikasinya bagi Pemerintahan Daerah di Indonesia." Journal of Political Science Universitas Hasanuddin 2(1): 97 12.

Sulardi, S., Sulistyaningsih, T. 2017. 'Konstruksi Regulasi Sistem Pemilihan Kepala Daerah Menuju Sistem Pemilihan Kepala Daerah yang Demokratis dan Aspiratif." Media Hukum 24(1): 24-10. https://doi.org/10.18196/jmh.2017.0086.24-34

Tempo. 2015. Sulap Anggaran Perangsang Dukungan. Retrieved August 9, 2019 (https://majalah.tempo.co/read/laporanutama/148707/sulap-anggaranperangsang-dukungan).

Tribun Medan. 2018. Alasan NasDem Alihkan Dukungan dari Tengku Erry Kepada Edy. Retrieved June 15, 2019 (https://www.tribunnews.com/nasional/2018/01/05/ alasannasdem-alihkan-dukungan-dari-tengku-erry-kepadaedy-rahmayadi?page=all)

Tribun Medan. 2018. Seleksi Komisaris dan Dewan Pengawas BUMD Sumut Sabrina: 76 Orang Masih Tahap Ujian Tertulis. Retrieved June 2019 (http://medan.tribunnews.com/ 2018/12/17/seleksi-komisaris-dan-dewanpengawas-bumdsumut-sabrina-76-orang-masih-tahap-ujian-tertulis). 
Utari, I. S. 2016. "Pencegahan Politik Uang dan Penyelenggaraan Pilkada yang Berkualitas: Sebuah Revitalisasi Ideologi." Seminar Nasional Hukum Universitas Negeri Semarang 2(1): 451-23.

Van, G. K. 2002. "Indonesia's New Ethnic Elites. In Henk Schulte Nordholt and Irwan Abdullah (eds.)" Yogykarta: Pustaka Pelajar, pp. 67-38.

Received on 15-02-2021

Accepted on 21-04-2021

Published on 26-04-2021

https://doi.org/10.6000/1929-4409.2021.10.100

(C) 2021 Muryanto Amin; Licensee Lifescience Global.

This is an open access article licensed under the terms of the Creative Commons Attribution Non-Commercial License (http://creativecommons.org/licenses/by-nc/3.0/) which permits unrestricted, non-commercial use, distribution and reproduction in any medium, provided the work is properly cited.
Wulandari L. 2014. Politik Biaya Tinggi dalam Pemilihan Kepala Daerah. Perludem. Retrieved April 16, 2019 (https://www.academia.edu/6980685/Laporan_Penelitian_ Biaya_Politik_Pilkada_Studi_Kasus_Pilkada_Garut_Lia). 